\title{
Electrochemical characterisation of the porosity and corrosion resistance of electrochemically deposited metal coatings
}

\author{
F.C. Walsh ${ }^{\mathrm{a}, *}$, C. Ponce de León ${ }^{\mathrm{a}}$, C. Kerr $^{\mathrm{b}}$, S. Court ${ }^{\mathrm{c}}$, B.D. Barker ${ }^{\mathrm{c}}$

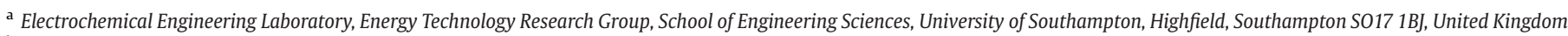 \\ b Tin Technology Ltd., Unit 3, Curo Park, Frogmore, St. Albans, Herts. AL2 2DD, United Kingdom \\ c Applied Electrochemistry Group, University of Portsmouth, St. Michael's Building, White Swan Road, Portsmouth P01 2DT, United Kingdom
}

\section{A R T I C L E I N F O}

\section{Article history:}

Received 30 November 2007

Accepted in revised form 8 May 2008

Available online 17 May 2008

\section{Keywords:}

Corrosion resistance

Corrosion testing

Current vs. time

Linear polarisation resistance

Electroless nickel coatings

Polarisation curves

Porosity

Tafel extrapolation

\begin{abstract}
A B S T R A C T
Electrochemical techniques for the assessment of porosity in electrodeposited metal coatings are reviewed. The determination of porosity and corrosion, resistance is illustrated by electrochemical data from three coating/ substrate systems namely: electroless nickel on aluminium and steel and immersed gold coatings on an electroless copper-plated ABS polymer. Nickel coatings were up to $24 \mu \mathrm{m}$ thick while gold deposits had thickness between 75 and $190 \mathrm{~nm}$. Tafel extrapolation and linear polarisation resistance methods were used to determine the corrosion rate of the coated substrates. The aluminium samples were tested in $5 \% \mathrm{w} / \mathrm{v}\left(0.85 \mathrm{~mol} \mathrm{dm}^{-3}\right) \mathrm{NaCl}$, while coated steel and ABS samples were immersed in $0.125 \mathrm{~mol} \mathrm{dm}^{-3} \mathrm{H}_{2} \mathrm{SO}_{4}$ and $0.1 \mathrm{~mol} \mathrm{dm}^{-3} \mathrm{NaBH}_{4}$, respectively, at $295 \mathrm{~K}$. Current vs. time curves and anodic polarisation behaviour have also been considered.
\end{abstract}

(C) 2008 Elsevier B.V. All rights reserved.

\section{Introduction}

Through-porosity is an important parameter that should be assessed to estimate the life expectancy of coated components and their quality. Porosity in the coating is strongly related to the corrosion resistance of the substrate [1]. For example, a galvanic cell can be formed in an electroless nickel (EN) coating on aluminium or steel immersed in an acid. This galvanic cell promotes substrate dissolution and hydrogen evolution (or oxygen reduction) on the nickel coating. The noble nickel coating can also be dissolved in the acidic environment increasing the pore size and number, accelerating localised corrosion of the (base) substrate.

In the case of electroless coatings, the corrosion resistance depends on the phosphorus content [2]; for example, high corrosion resistance in acidic environments have been achieved at $>10 \%$ phosphorus content while low $(<4 \%)$ phosphorus content coatings tend to perform well in alkaline electrolytes [3] and at elevated temperatures [4].

For comparable pre-treatment schedules, the porosity of EN coatings has been shown to be much lower than that in nickel electrodeposits from a Watts bath [5]. The porosity of EN coatings is linked to a number of factors that decrease the corrosion resistance of the coated substrate, such as: aged baths [6], inadequate substrate pretreatment $[7,8]$, surface roughness [9-11] and coating microstructure

\footnotetext{
* Corresponding author.

E-mail address: F.C.Walsh@soton.ac.uk (F.C. Walsh).
}

[12]. Porosity can be affected by heat treatment due to the shrinking of the coating when its structure changes from amorphous to crystalline during the curing process, exposing part of the substrate [13].

\subsection{Porosity tests}

There are numerous chemical and electrochemical porosity tests in the literature. Chemical porosity tests include neutral and acetic acid salt spray, sulfur dioxide exposure, the use of a ferroxyl indicator and corrodkote corrosion tests $[10,14]$. Such tests are designed to attack the substrate revealing the corrosion occurring through the pores. However, corrosion products could block the pores and give false readings while very fine pores are hard to penetrate by the electrolyte and may be missed. These tests often take a long time and visual results can be difficult to quantify and reproduce [15]. In contrast, electrochemical technologies can be rapid and more reliable. A classical example is the electrographic test where a current is passed between the test specimen (anode) and an inert cathode. An absorbent paper soaked in an electrolyte containing a colorimetric indicator is sandwiched between the two electrodes. The current reveals coloured areas on the paper due to the reaction between the indicator in the electrolyte and the dissolved metal ions from the test specimen showing the location of the pores. A disadvantage is that very small pores can be missed with this technique; it is also important to chose appropriate electrolyte (and indicator) composition and the duration of the test. Other electrochemical tests, such as Tafel extrapolation, cyclic voltammetry, linear polarization resistance 


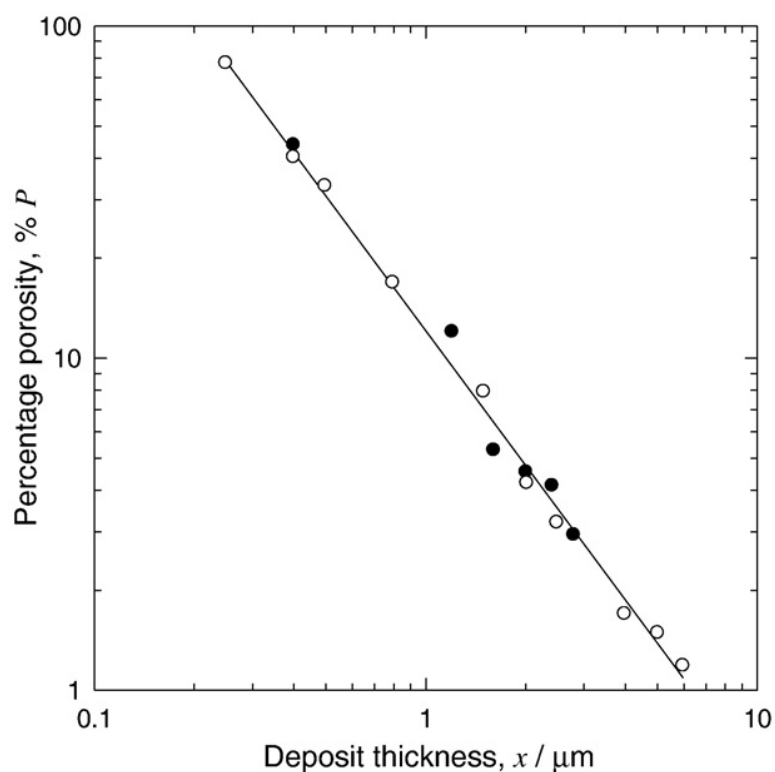

Fig. 1. Log-log plot of percentage porosity $v s$. coating thickness for electroless nickel deposits on steel in $0.125 \mathrm{~mol} \mathrm{dm}^{-3} \mathrm{H}_{2} \mathrm{SO}_{4}$ at $295 \mathrm{~K}$. Data obtained by cyclic voltammetry. ) Nahlé et al. [22]; and O) recent data obtained by Walsh et al. [unpublished work].

and corrosion potential monitoring, are more quantitative and can be performed rapidly with standard electrochemical instrumentation [16-18]. Such techniques have been used to determine the percentage through-porosity in electroless nickel coatings on steel and aluminium substrates [19-22].

Electrochemical methods can be used to expose the underlying substrate in a carefully chosen electrolyte. An appropriate electrolyte will allow contact with the substrate through pores in the deposit and with the coating material. The two metals form a bimetallic corrosion cell. If the coating is noble respect to the substrate, the deposit should be pore-free to avoid a high cathode to anode area ratio, which can lead to intense, localised corrosion of the substrate. This is especially true for thin immersion deposits. Continuous electroless deposition of metal may slowly fill any pores left in previous coating layers [4].

In many cases, the general relationship between the porosity $(P)$ and a uniformly deposited coating of thickness $(x)$ takes the form [23]:

$P=A x^{n}$

where $A$ and $n$ are empirical constants that depend on pre-treatment, plating time and process conditions [5]. Fig. 1 shows an example of the relationship between percentage porosity and deposit thickness. The porosity was determined by cyclic voltammetry carried out on nickelcoated steel samples. The charge under the anodic peaks when the potential was swept towards negative values was measured for different thickness of nickel coated samples. The potential range and the electrolyte selected are such that anodic dissolution of the substrate occurs but nickel dissolution is negligible or occurs outside the potential range, at more positive potentials. The charge under the anodic peak without nickel coating was considered to represent $100 \%$ porosity while the charge exhibited by the samples with nickel coating was linearly correlated to the percentage of porosity [22]. The log-log plot of percentage porosity vs. nickel deposit thickness corresponds to the logarithmic form of Eq. (1):

$\log P=\log A+n \log X$.

Such a plot shows reasonable linearity over a thickness range between 0.2 and $6 \mu \mathrm{m}$ with a correlation coefficient, $r^{2}$ of 0.997 . If $x$ has units of $\mu \mathrm{m}$, the values of the constants $A$ and $n$ are 12 and -1.35 , respectively. The size, geometry and chemical homogeneity of the pores are not taken into account in this equation but it provides a reasonable approximation of the porosity over a wide range of coating thickness, for a uniform thickness specific coating substrate-test protocol.

\section{Electrochemical techniques}

In the case of a noble metal coating, the simplified electrode reactions during corrosion of an iron substrate in acid are typically:

Anodic reaction : $\mathrm{Fe}^{-} 2 \mathrm{e}^{-} \rightarrow \mathrm{Fe}^{2+} \quad \mathrm{E}^{0}=-0.447$ vs. SHE

Cathodic reaction : $2 \mathrm{H}^{+}+2 \mathrm{e}^{-} \rightarrow \mathrm{H}_{2} \quad \mathrm{E}^{0}=0.000$ us. SHE

or : $1 / 2 \mathrm{O}_{2}+2 \mathrm{H}^{+}+2 \mathrm{e}^{-} \rightarrow \mathrm{H}_{2} \mathrm{O} \quad \mathrm{E}^{0}=1.229$ us. SHE

Corrosion cell reaction : $\mathrm{Fe}+2 \mathrm{H}^{+} \rightarrow \mathrm{Fe}^{2+}+\mathrm{H}_{2}$.

These reactions can be used to estimate the percentage of porosity. The most common electrochemical techniques used for this purpose are summarized in Table 1 and are explained in the Section 2.1.

In this paper, the emphasis is on direct current (d.c.) techniques. The reader is referred elsewhere for studies of porosity using a.c. techniques such as electrochemical impedance spectroscopy [24-26]. EIS can provide a powerful tool for electrochemical measurements on metal coating integrity but presents the problem of interpretation of complex data. For example, Zhang et al. suggested an equivalent circuit to measure the morphological properties of plasma [24]

Table 1

Direct current (d.c.) electrochemical techniques considered in this paper and their features

\begin{tabular}{|c|c|c|c|c|c|}
\hline Technique & Principle & Example & Advantages & Disadvantages & Ref. \\
\hline $\begin{array}{l}\text { Current } \\
\text { density vs. } \\
\text { time, } j \text { vs. } t \text { at } E\end{array}$ & $\begin{array}{l}\text { Measure the dissolution } j \text { of coated } \\
\text { samples at a fixed potential, } E\end{array}$ & $\begin{array}{l}\text { Immersion } \\
\text { deposits of } \\
\text { Ni on steel }\end{array}$ & $\begin{array}{l}\text { The curve yields the total charge due to the dissolving } \\
\text { metal reflecting the rate of dissolution and the } \\
\text { integrity of the coating. } 30 \text { to } 60 \mathrm{~min}\end{array}$ & $\begin{array}{l}\text { The surface conditions are not the same } \\
\text { as when the surface is at the open-circuit } \\
\text { potential }\end{array}$ & [15] \\
\hline $\begin{array}{l}\text { Anodic } \\
\text { polarisation, } \\
\text { Evs. } \log j\end{array}$ & $\begin{array}{l}\text { Potential sweep to a value } \approx 2 \mathrm{~V} \\
\text { anodic to the } E_{\text {cor }} \text { value }\end{array}$ & $\begin{array}{l}\text { Ni on mild } \\
\text { steel }\end{array}$ & $\begin{array}{l}\text { Porous and non-porous deposits exhibit different anodic } \\
\text { behaviour. Time to perform the test: } 60 \text { to } 90 \mathrm{~min}\end{array}$ & $\begin{array}{l}\text { Similar to the above, the surface is } \\
\text { different due to the imposed current and } \\
\text { real corrosion conditions are an } \\
\text { approximation }\end{array}$ & {$[7,15]$} \\
\hline $\begin{array}{l}\text { Tafel } \\
\text { behaviour, } E \text { vs. } \\
\log j\end{array}$ & $\begin{array}{l}\text { Potential sweep to a value } \approx 0.15 \mathrm{~V} \\
\text { either side of } E_{\text {rest }} \text { or } E_{\text {cor }} \text { Corrosion } \\
\text { data can be deduced }\end{array}$ & $\begin{array}{l}\text { Electroless } \\
\text { Ni on mild } \\
\text { steel }\end{array}$ & $\begin{array}{l}\text { Corrosion measurements of coated substrates. } \\
\text { Typically } 30 \mathrm{~min} \text { to complete }\end{array}$ & $\begin{array}{l}\text { The Tafel slope can be difficult to } \\
\text { determine }\end{array}$ & {$[7,15,29]$} \\
\hline $\begin{array}{l}\text { Potential vs. } \\
\text { time, } E_{\text {cor }} v s . t\end{array}$ & $\begin{array}{l}\text { Potential within a given } \\
\text { environment over time }\end{array}$ & $\begin{array}{l}\text { Electroless } \\
\text { Ni on pyrene } \\
\text { steel }\end{array}$ & $\begin{array}{l}\text { Non-porous coatings have a more noble potential } \\
\text { compared to porous. } 30 \text { to } 60 \text { min to complete }\end{array}$ & $\begin{array}{l}\text { Oxide formation and substrate activity } \\
\text { should be considered }\end{array}$ & {$[7,9,27]$} \\
\hline LPR, E vs. I & $\begin{array}{l}\text { Potential sweep to a value of } \\
\approx 0.05 \mathrm{~V} \text { either side of } E_{\text {rest }} \text { or } E_{\text {cor }}\end{array}$ & $\begin{array}{l}\text { Electroless } \\
\mathrm{Ni} \text { on } \mathrm{Al} \text { or } \mathrm{Ni} \\
\text { on } \mathrm{Fe}\end{array}$ & $\begin{array}{l}\text { Rapid (10 min) reproducible method to find corrosion } \\
\text { rates }\end{array}$ & $\begin{array}{l}\text { Although disruptions to surface are } \\
\text { minimal, it still influences the surface } \\
\text { conditions }\end{array}$ & {$[7,9]$} \\
\hline $\begin{array}{l}\text { Cyclic } \\
\text { voltammetry } \\
\text { Evs. J }\end{array}$ & $\begin{array}{l}\text { Potential sweep from }-0.5 \text { to }+0.5 \\
\text { back to }-0.5 \mathrm{~V} v s \text {. SCE }\end{array}$ & $\begin{array}{l}\text { Electroless } \\
\text { Ni coating on } \\
\text { Al }\end{array}$ & $\begin{array}{l}\text { Rapid (10 min) simple electrochemical } \\
\text { instrumentation }\end{array}$ & $\begin{array}{l}\text { Charge } v \text { s. covered surface may be non- } \\
\text { linear due to other reactions, e.g. } \mathrm{H}_{2} \\
\text { evolution }\end{array}$ & {$[20]$} \\
\hline
\end{tabular}


sprayed thermal barriers coatings. The porosity of the coating was proportional to the ceramic capacitance while the pore shape was estimated by the pore resistance. Ahm et al. [25] evaluated the porosity of $\mathrm{WC}-\mathrm{Cr}_{1-x} \mathrm{Al}_{x} \mathrm{~N}$ coatings on high speed steel using EIS. Creus et al. [26] determined the porosity of 3-10 $\mu \mathrm{m} \mathrm{Al}$, Ti, TiN and $\mathrm{CrN}$ protective coatings on steel after $1 \mathrm{~h}$ immersion in $3 \% \mathrm{NaCl}$ from the faradic capacity of the coated steel. However, the porosity measurements critically depended on the immersion time which determines the charge transfer resistance and can only be accurate if rapid dissolution of the substrate and accumulation of the corrosion products in the pores can be eliminated [25]. Creus et al., [26] found that the porosity obtained from d.c. techniques such as polarization resistance, mixed potential theory and polarization curves and EIS were similar. They also suggested that sophisticated methods such as EIS could be avoided, in some cases, simple (direct current) polarisation resistance methods can give precise porosity values.

\subsection{Linear polarisation resistance (LPR) measurements}

If the potential is displaced by $\pm(0.01-0.02 \mathrm{~V})$ from the corrosion potential $E_{\text {cor }}$, the plot of polarisation $v s$. current density is approximately linear and the linear polarization resistance can be found from the slope of the graph is the (LPR) [27,28]. Stern [29] developed a relationship between the slope value and the corrosion current density, $j_{\text {cor }}$, a simplified form of this expression being:

$\frac{\Delta E}{\Delta j}=\frac{\beta_{a}\left|\beta_{c}\right|}{2.3 j_{\text {cor }}\left(\beta_{a}+\left|\beta_{c}\right|\right)}$

where $\beta_{a}$ and $\beta_{c}$ are the anodic and cathodic Tafel slopes, respectively, and $\Delta E / \Delta j$ is the slope of the linear polarisation curve. The slope of the linear polarisation curve is mainly controlled by the corrosion current density, $j_{\text {cor }}$ which is relatively insensitive to the anodic and cathodic Tafel slopes. Hence, it is possible to formulate a reasonably accurate approximation of Eq. (6) assuming $\beta_{\mathrm{a}}=0.06 \mathrm{~V}$ and $\beta_{\mathrm{c}}=0.12 \mathrm{~V}$ [30]. Eq. (6) may be further simplified to:

$\frac{\Delta E}{\Delta j}=\frac{0.017}{j_{\text {cor }}} \quad$ or $\quad j_{\text {corr }}=\frac{0.017 \Delta j}{\Delta E}$.

The accuracy of this approximation is not always sufficient but the equation can be used in most corrosion systems and provides a unique, simple and rapid method for the estimation of corrosion rates.

\subsection{Tafel extrapolation (log current vs. potential) diagrams}

In this technique, the metal under investigation is used as a working electrode and immersed in the chosen electrolyte [31]. From the corrosion potential, $E_{\text {cor }}$, small potential steps in the negative direction are taken until the electrode becomes completely cathodic. The rate of the cathodic process can be determined by monitoring the current $v s$. time at each potential step. The polarization value, $\eta_{c}$, can be obtained by:

$\eta_{c}=E_{\text {meas }}-E_{c o r}$

where $E_{\text {meas }}$ is the potential value away from $E_{\text {cor }}$ under charge transport controlled conditions. The relationship between the current flowing and the cathodic polarisation is given by the Tafel equation:

$\eta_{c}=\beta_{c} \log j_{o}-\beta_{c} \log j$.

The plot of $\eta_{c} v s . \log j$ is a straight line at $\eta_{c}<-0.05 \mathrm{~V}$ while at less negative polarisations the curve contains the contribution of the anodic current. Extrapolation of the linear cathodic section to $\eta_{c}=0$ ( $E_{\text {cor }}$ value) yield the corrosion current density, $j_{\text {cor }}$. The Tafel equation for the anodic process is similar and should give the same value of the corrosion current density according to the mixed potential theory [32].

\subsection{Cyclic voltammetry}

The charge under the curve of the anodic peaks can be related to the percentage of substrate exposed to the electrolyte. An example of this method was briefly considered in the introduction for electroless nickel coating on steel. The samples were prepared by immersing the steel strips in an electroless nickel bath at different times. Samples immersed for 2, 14 and 30 min developed Ni coatings of approximately $0.4,2.8$ and $6 \mu \mathrm{m}$ thickness, respectively. Voltammograms of each coated sample were obtained by sweeping the potential towards negative values at a linear sweep rate of $50 \mathrm{mV} \mathrm{s}^{-1}$ between -0.5 and $+0.5 \mathrm{~V}$ vs. SCE in $0.1 \mathrm{~mol} \mathrm{dm}^{-3} \mathrm{H}_{2} \mathrm{SO}_{4}$ and in $0.1 \mathrm{~mol} \mathrm{dm}^{-3} \mathrm{~K}_{4} \mathrm{Fe}(\mathrm{CN})_{6}$ electrolyte at $298 \mathrm{~K}$. The curves showed an anodic peak whose charge depended on the nickel coating thickness and the charge when no nickel was deposited was considered as $100 \%$ porous. The sample immersed in the nickel electroless bath for 30 min covered the whole steel surface and was considered $0 \%$ porous as the anodic peak showed none or little charge. Under these considerations the porosity of the 0.4 and $2.8 \mu \mathrm{m}$ Ni thickness coated samples was 56\% and 97\%, respectively [22]. This technique can be easily carried out with simple electrochemical equipment in approximately $10 \mathrm{~min}$.

\subsection{Current-time transients}

Controlling the anodic potential in the points where the slope of the anodic polarization curve, $\eta v s$. $j$, changes, can yield information of the reactions taking place on the surface. The levels of dissolved metal coating $(\mathrm{Ni})$ and the underlying metal $(\mathrm{Fe})$ will determine the predominant anodic dissolution process and can be directly related to the porosity of the coating deposit $[33,34]$.

\subsection{Corrosion potential measurements}

The open-circuit corrosion potential of porous deposits on a metal surface varies between the potential of the coating and the substrate. These measurements can therefore be used to assess whether the substrate is fully encased (pore-free deposit) and thereby resistant to corrosion in a given electrolyte or not. For example, the corrosion potentials $E_{\text {cor }}$, of aluminium ( $100 \%$ porous) and a $24 \mathrm{~m}$ thick electroless nickel coating on aluminium (assumed to be pore free) are $-0.86 \mathrm{~V}$ and $-0.42 \mathrm{~V} v$ s. SCE, respectively. Similarly, the corrosion potentials of mild steel and a $24 \mu \mathrm{m}$ (100\% pore-free) nickel coating mild steel in $0.125 \mathrm{~mol} \mathrm{dm}^{-3} \mathrm{H}_{2} \mathrm{SO}_{4}$ are -0.25 and $-0.47 \mathrm{~V} v$ s. SCE, respectively. Values of the corrosion potentials between these limits can be correlated to the degree of porosity. For thin $<6 \mu \mathrm{m}$, coatings, other effects such as oxide formation and the stronger activity of the substrate should be taken into account [20].

\section{Experimental details}

\subsection{Composition and plating conditions for aluminium substrates}

Aluminium alloy plates $(3105 \mathrm{H} 24)$ of $20 \times 50 \times 1 \mathrm{~mm}$ size were used for the corrosion studies. The composition of the alloy was $0.60 \% \mathrm{Si}$, $0.70 \% \mathrm{Fe}, 0.30 \% \mathrm{Cu}, 0.30-0.80 \% \mathrm{Mn}, 0.20-0.80 \% \mathrm{Mg}, 0.20 \% \mathrm{Cr}, 0.40 \% \mathrm{Zn}$ and $\approx 96.4 \%$ wt. Al. Each sample was pretreated by an alkaline degrease ( $\mathrm{pH} 7.2-8$ ) at 323-343 K [35], rinsed with deionised water and etched in acid, desmutting solution, typically $50 \% \mathrm{HNO}_{3}$ with added $\mathrm{H}_{2} \mathrm{SO}_{4}$ and fluoride ions to remove metallic oxides [36]. The aluminium substrates were then immersed twice in a zincate solution, rinsed in deionised water and acid etched in between. The full pre-treatment process is described in detail elsewhere [37]. The pre-treated aluminium substrates were plated with a commercial electroless nickel plating process (Fidelity 5010) at various times. A temperature of 363-365 K, the plating rate was approximately $4-6 \mu \mathrm{m} \mathrm{h}^{-1}$ and controlled deposition times 
were chosen to produce nickel coated samples of $0.5,1,3,6,12$ and $24 \mu \mathrm{m}$ thickness.

\subsection{Composition and plating conditions for mild steel substrates}

Panels of mild steel (Pyrene steel - 040A10 BS 970:1983) of $75 \times 25 \times 1 \mathrm{~mm}$ size were used. Prior to the electroless plating, the panels were degreased in a $10 \%$ concentration of a commercial alkaline soak cleaner (Fidelity 3152) for $10 \mathrm{~min}$ at 323-333 K, followed by $1 \mathrm{~min}$ rinse in deionised water and $2 \mathrm{~min}$ immersion in $50 \% \mathrm{HCl}$ solution. The process was repeated until complete removal of oxide surfaces was achieved. The pre-treatment of the mild steel is fully described elsewhere [20]. The panels were then coated in a highphosphorus, electroless nickel plating solution to achieve 1, 3, 6, 12, 18 and $24 \mu \mathrm{m}$ coating thickness.

\subsection{Composition and plating conditions for $A B S$ substrates}

Panels of ABS plastic, size $75 \times 25 \times 1 \mathrm{~mm}$, were used. The panels were degreased with a commercial alkaline soak cleaner Duraprep, (Duratech Industries Ltd.) rinsed with deionised water, acid etched (providing a good key for subsequent metallic coating) and rinsed again The panels were then immersed in a stannous chloride/ $\mathrm{HCl}$ solution followed by activation of the polymer surface with $\mathrm{PdCl}_{2}$ and a final double rinse with deionised water before applying a $30 \mu \mathrm{m}$ electroless copper deposit. This was followed by immersing the panels in a gold containing solution for controlled periods of time to achieve gold deposit of nominally $0,75,100$ and $190 \times \mathrm{nm}$ thickness. The ABS samples were rinsed in deionised water, washed with ethanol, dried with a hot air and stored in a dessicator. The ABS pre-treatment is fully described elsewhere [1].

\subsection{Choice of electrolyte}

The nature of the electrolyte is critical to keep the corrosion of the deposit as low as possible. It is assuming that the current flowing from the electrode is due to the corrosion of the substrate together with dissolved ions passing through the existing pores of the coating. Electrochemical measurements of the three samples described above were carried out at $295 \mathrm{~K}$ as follows: (i) aluminium substrate samples in $0.85 \mathrm{~mol} \mathrm{dm}^{-3}$ (5\%) sodium chloride electrolyte, (ii) mild steel coupons in $0.125 \mathrm{~mol} \mathrm{dm}^{-3}$ sulfuric acid and (iii) gold copper-coated ABS plastic samples in a $0.1 \mathrm{~mol} \mathrm{dm}{ }^{-3} \mathrm{NH}_{4} \mathrm{BF}_{4}$ electrolyte.

The chemicals used in the experiments were analytical grade and the solutions were prepared with deionised water. All the experiments were carried out in triplicate using a saturated calomel reference electrode (SCE) and a $4 \mathrm{~cm}^{2}$ Pt mesh counter electrode.

\subsection{Tafel extrapolation, anodic polarisation and current-time transients}

A PAR EG \& G potentiostat (model 273A) was used to apply a linear potential sweep rate of $1 \mathrm{mV} \mathrm{s}^{-1}$ for all the electrochemical tests. The experimental arrangement including a two-compartment electrochemical glass cell $\left(300 \mathrm{~cm}^{3}\right)$ containing 3-electrodes as illustrated in Fig. 2. This cell was used for the majority of the experiments. The linear polarization resistance (LPR) and corrosion potential measurements were carried out in a $250 \mathrm{~cm}^{3}$ beaker. The

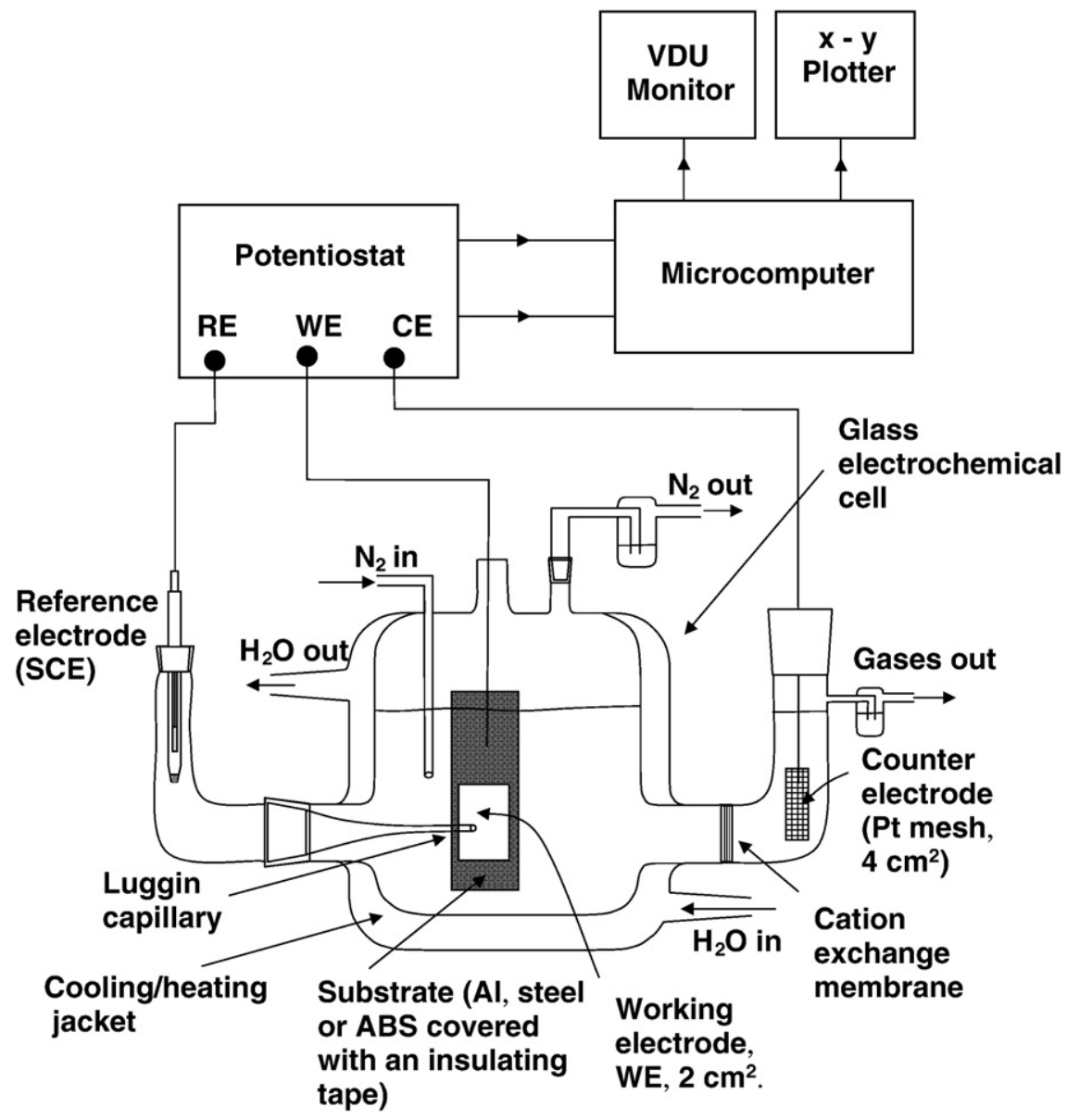

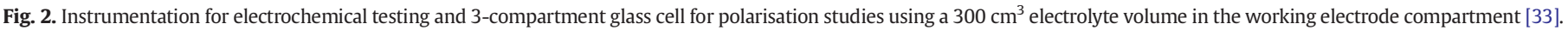




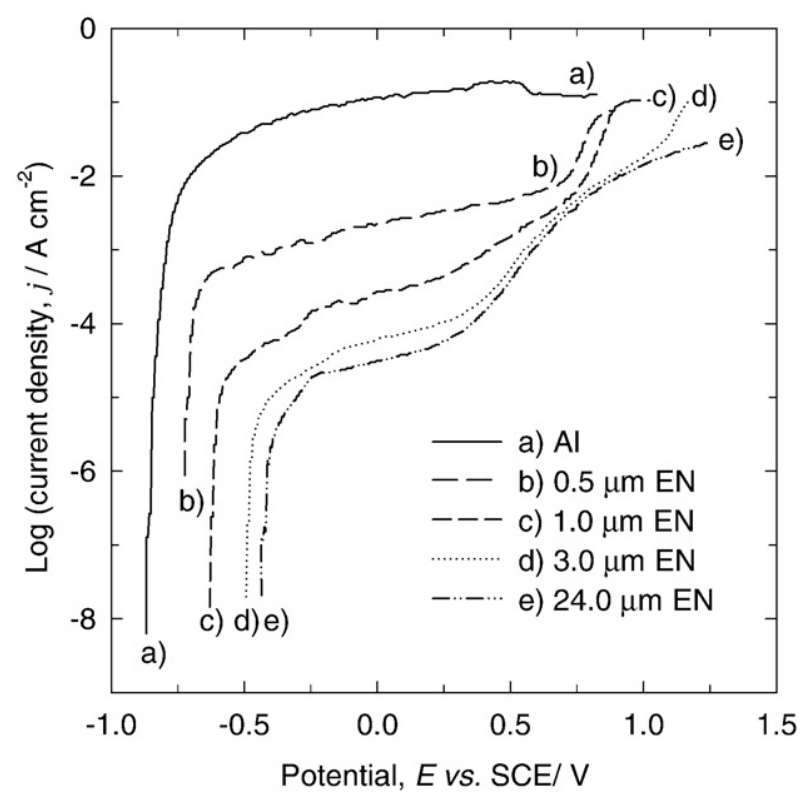

Fig. 3. Log current density vs. potential for various thicknesses of electroless nickelphosphorous deposits on aluminium in $0.85 \mathrm{~mol} \mathrm{dm}^{-3}(5 \% \mathrm{w} / \mathrm{w}) \mathrm{NaCl}$ at $295 \mathrm{~K}$; a) bare $\mathrm{Al}$ and $\mathrm{Al}$ with: b) $0.5 \mu \mathrm{m} \mathrm{Ni}$, c) $1 \mu \mathrm{m} \mathrm{Ni}$, d) $3 \mu \mathrm{m} \mathrm{Ni}$ and e) $24 \mu \mathrm{m}$ Ni coatings.

plated samples were polarised from -0.25 to $+0.25 \mathrm{~V} v s$. SCE (Tafel measurements) and -0.25 to $+0.16 \mathrm{~V}$ vs. SCE (anodic polarisation measurements). Current $v$ s. time transients were obtained at various constant potentials, previously identified on the anodic polarisation curves, for $60 \mathrm{~min}$.

\subsection{Linear polarisation resistance and corrosion potential}

Identical coupons of the samples coated with electroless nickel were covered with an insulating masking tape leaving $1 \mathrm{~cm}^{2}$ area exposed and were attached to a twin electrode LPR meter (SSL Ltd.). The meter was internally calibrated to give an average corrosion reading in terms of the estimated penetration rate in $\mathrm{mm} \mathrm{yr}^{-1}$. In parallel with the LPR readings, corrosion potential $\left(E_{\text {cor }}\right)$ measure-

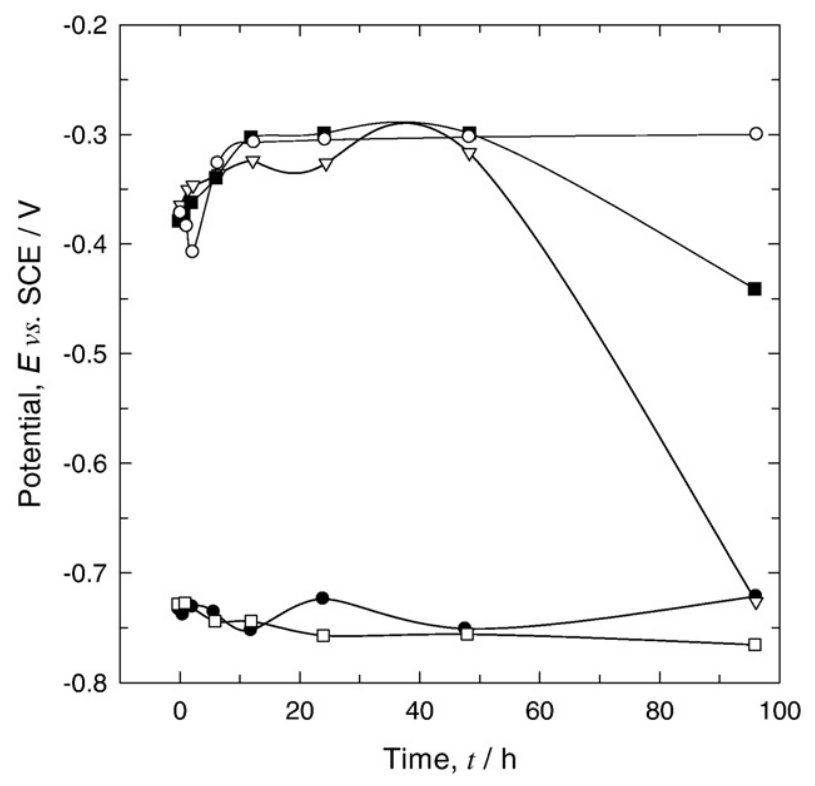

Fig. 5. Corrosion potential $v s$. time behaviour of aluminium substrate samples coated with different thickness of electroless nickel deposit immersed in $0.85 \mathrm{~mol} \mathrm{dm}^{-3}(5 \%) \mathrm{NaCl}$ at 295 Kover $96 \mathrm{~h}: \bullet) 0 \mu \mathrm{m}, \square) 0.5 \mu \mathrm{m}, \mathrm{s} \nabla) 3 \mu \mathrm{m}, \mathbf{\square}) 6 \mu \mathrm{m}$, and O) $24 \mu \mathrm{m}$ electroless Ni coating.

ments $( \pm 0.002 \mathrm{~V})$ vs. SCE were taken over $96 \mathrm{~h}$, using a high impedance digital voltmeter (Iso-Tech IDM 201).

\section{Results and discussion}

\subsection{Porosity of electroless nickel coatings on an aluminium alloy substrate}

\subsubsection{Anodic polarisation}

Fig. 3 shows the logarithm of the current density vs. potential behaviour for the aluminium alloy samples. The curves represent the bare alloy and samples covered with 0.5, 1.0, 3.0 and $24 \mu \mathrm{m}$ electroless nickel (EN) coating in $0.85 \mathrm{~mol} \mathrm{dm}^{-3}(5 \%) \mathrm{NaCl}$ solution. All curves have a horizontal region of steady current as the potential increases indicating the formation of a passive film on the nickel deposits. The passive film for the $24 \mu \mathrm{m}$ thick coating, which was assumed to be pore free, appears to

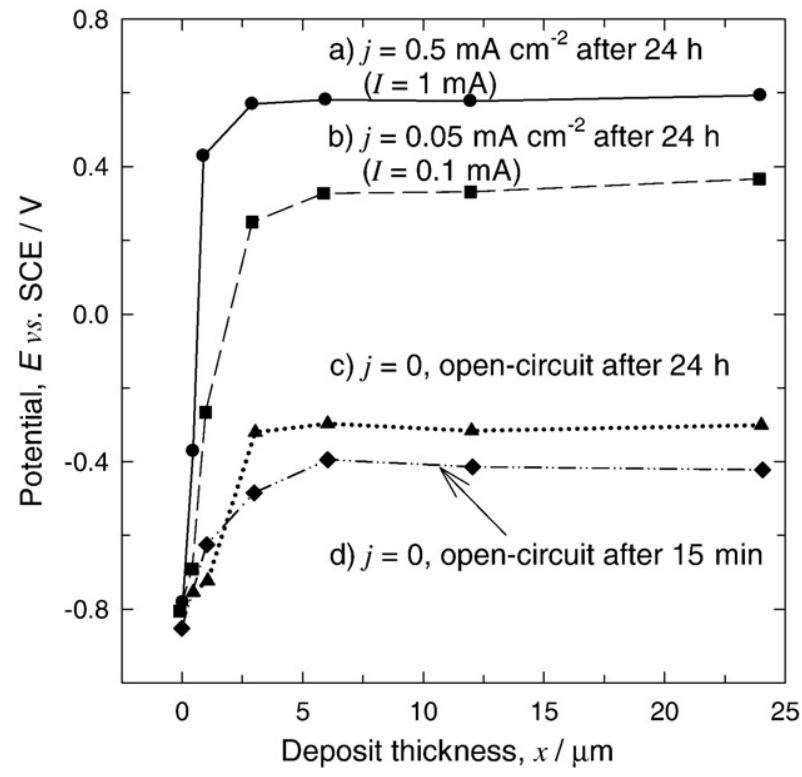

Fig. 4. Corrosion potential vs. electroless nickel coating thickness in $0.85 \mathrm{~mol} \mathrm{dm}^{-3}(5 \%) \mathrm{NaCl}$ at $295 \mathrm{~K}$ on an Al substrate. Anodic polarisation curves at different currents; a) $0.5 \mathrm{~mA} \mathrm{~cm}^{-2}$, b) $0.05 \mathrm{~mA} \mathrm{~cm}^{-2}$, c) zero current (open-circuit) and d) open-circuit after $24 \mathrm{~h}$.

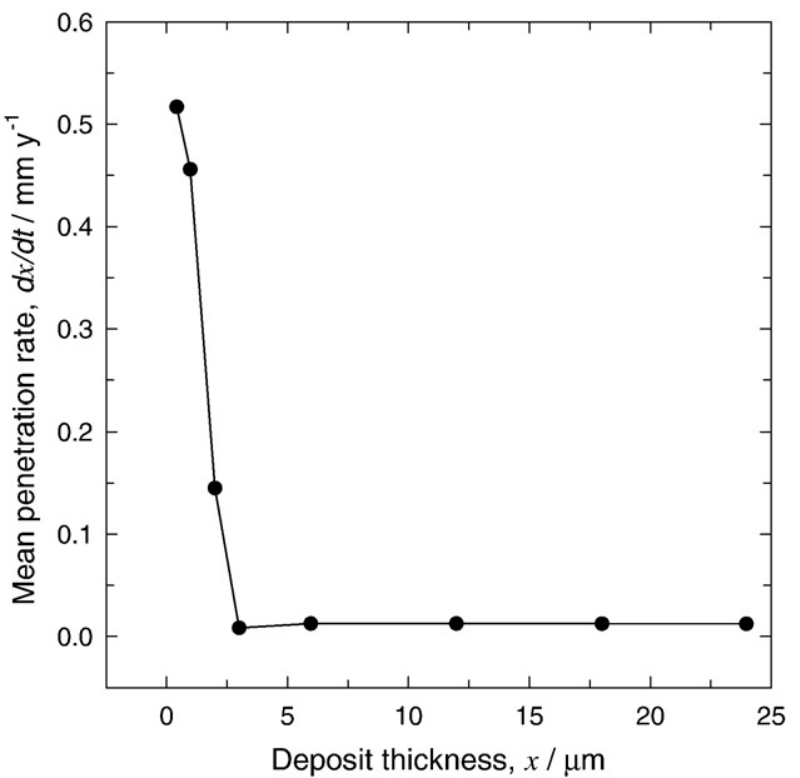

Fig. 6. Corrosion rate (measured by linear polarisation resistance) vs. electroless nickel coating thickness on aluminium in $0.85 \mathrm{~mol} \mathrm{dm}^{-3}(5 \%) \mathrm{NaCl}$ at $295 \mathrm{~K}$. 
a)

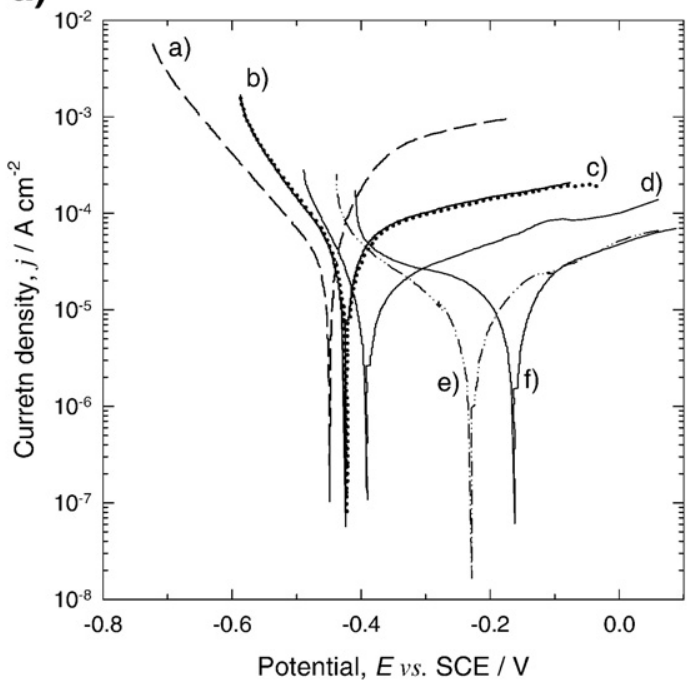

b)

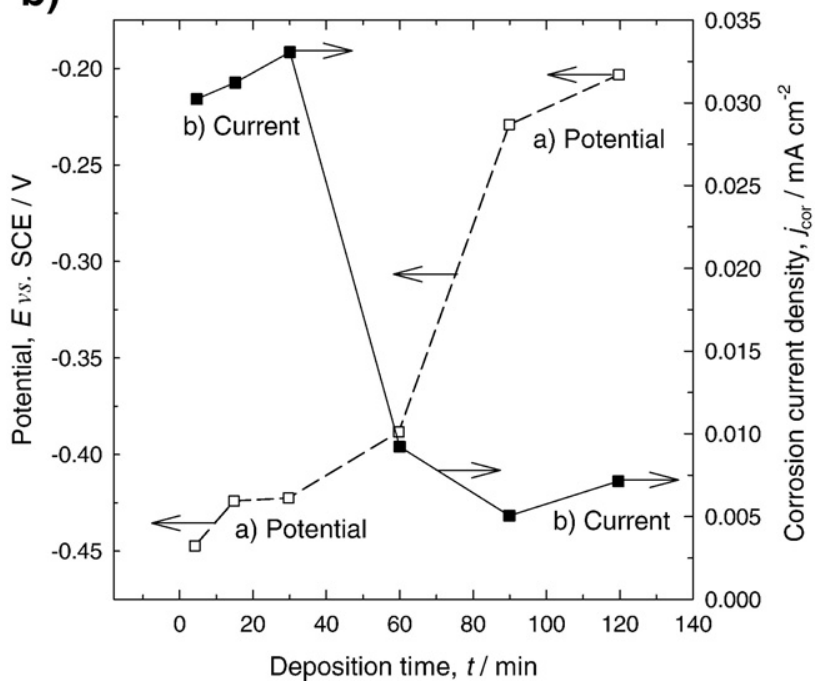

Fig. 7. a) Cathodic Tafel extrapolation plots of mild steel samples coated with various thicknesses of electroless nickel deposits immersed in $0.125 \mathrm{~mol} \mathrm{dm}^{-3} \mathrm{H}_{2} \mathrm{SO}_{4}$ at $295 \mathrm{~K}$. Deposit thickness: a) $1 \mu \mathrm{m}$, b) $3 \mu \mathrm{m}$, c) $6 \mu \mathrm{m}$, d) $12 \mu \mathrm{m}$, e) $18 \mu \mathrm{m}$ and f) $24 \mu \mathrm{m}$. b) Corrosion potential and corrosion current vs. deposition time obtained from a Tafel plot (Figure a): a) $E_{\text {cor, }}$ b) $j_{\text {cor }}$

break down at about $+0.25 \mathrm{~V} v$ s. SCE before the thinner coatings. Despite this increase of current probably due to the gradual opening of pores on the coating, the current is still $10^{-4} \mathrm{~A} \mathrm{~cm}^{-2}$ at this potential which shows the substantial protection provided by the EN coating. The bare aluminium alloy at this potential corrodes at $0.1 \mathrm{~A} \mathrm{~cm}^{-2}$. The current of

Table 2

Tafel analyses for mild steel and various electroless nickel deposits in $0.1 \mathrm{~mol} \mathrm{dm}^{-3}$ $\mathrm{H}_{2} \mathrm{SO}_{4}$ at a temperature of $295 \mathrm{~K}$

\begin{tabular}{llll}
\hline $\begin{array}{l}\text { Deposit thickness, } x / \mathrm{m} \\
\text { (Letter in Fig. 7 a) }\end{array}$ & $\begin{array}{l}\text { Corrosion } \\
\text { potential, } E_{\text {cor }} v s . \\
\text { SCE/V }\end{array}$ & $\begin{array}{l}\text { Corrosion current } \\
\text { density, } j_{\text {cor }} / \mathrm{A} \mathrm{cm}^{-2}\end{array}$ & $\begin{array}{l}\text { Mean corrosion } \\
\text { rate } / \mathrm{mm} \mathrm{yr}^{-1}\end{array}$ \\
\hline 0 (uncoated mild steel) & -0.540 & 61 & 0.75 \\
1 (a) & -0.450 & 30 & 0.37 \\
3 (b) & -0.425 & 30 & 0.37 \\
6 (c) & -0.420 & 30 & 0.37 \\
12 (d) & -0.390 & 9 & 0.11 \\
18 (e) & -0.230 & 6 & 0.089 \\
24 (f) & -0.165 & 7 & 0.085 \\
\hline
\end{tabular}

thinner coatings lies between the $10^{-4}$ and $10^{-3} \mathrm{~A} \mathrm{~cm}^{-2}$ at this potential but they break down at approximately $+0.75 \mathrm{~V} v$ s. SCE generating a dissolution current of approximately $0.01 \mathrm{~A} \mathrm{~cm}^{-2}$, which is still an order of magnitude lower than the current generated at the bare aluminium alloy.

\subsubsection{Dissolution potential measurements}

Fig. 4 shows the potential $(E)$, of the EN-coated aluminium alloy samples $v s$. the deposit thickness at selected current densities. The samples were immersed in $0.85 \mathrm{~mol} \mathrm{dm}^{-3}(5 \%) \mathrm{NaCl}$ solution. The open-circuit potential (OCP) of the samples after $15 \mathrm{~min}$ and $24 \mathrm{~h}$ of the deposition, increased from $\approx-0.9 \mathrm{~V}$ for the bare aluminium substrate (see Fig. 3 ) to -0.3 and $-0.4 \mathrm{~V} v$ s. SCE respectively when the nickel coating was $>5 \mathrm{~m} \mu$ thick. This potential difference is due to the

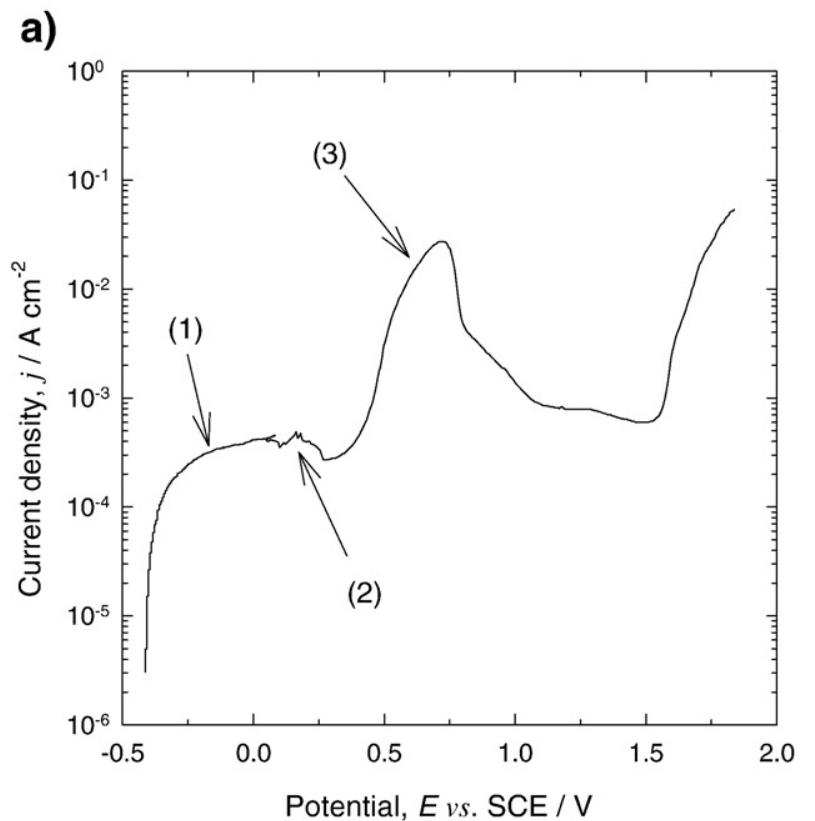

b)

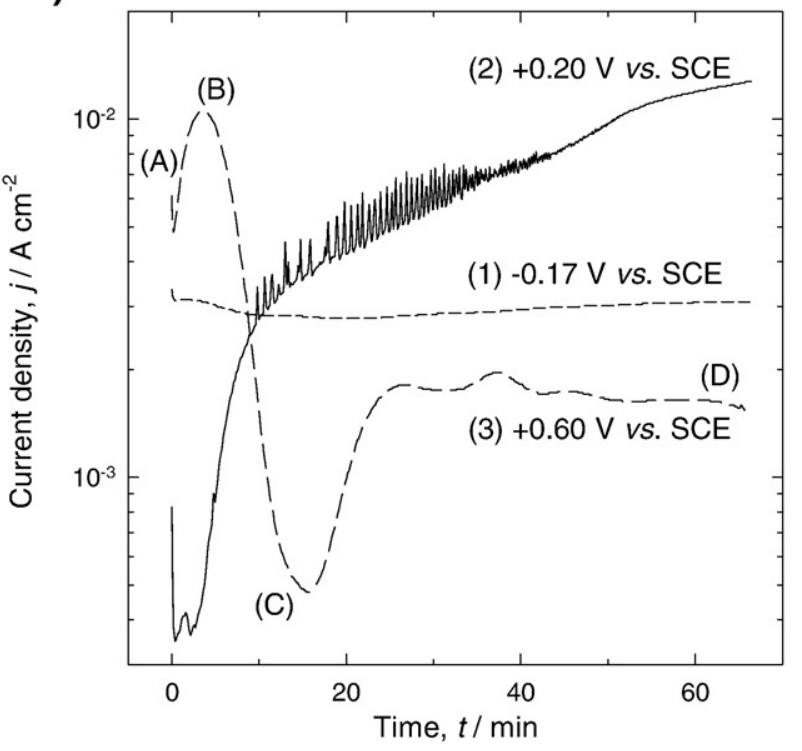

Fig. 8. a) Log current density vs. potential for a $1 \mu \mathrm{m}$ thickness electroless nickel-12\% phosphorus deposit on mild steel. b) Current vs. time at the potential indicated in the points of figure a: (1) $-0.17 \mathrm{~V},(2)+0.2 \mathrm{~V}$ and (3) $+0.6 \mathrm{~V}$ vs. SCE. The electrolyte $\left(0.125 \mathrm{~mol} \mathrm{dm}^{-3} \mathrm{H}_{2} \mathrm{SO}_{4}\right.$ at $295 \mathrm{~K}$ ), was analysed for $\mathrm{Ni}^{2+}$ and $\mathrm{Fe}^{2+}$ ions for all experiments at the points $\mathrm{A}, \mathrm{B}, \mathrm{C}$ and $\mathrm{D}$. 
fact that the open-circuit potential immediately after the deposition was taken from the anodic polarisation curve and the equilibrium, which takes approximately $15 \mathrm{~min}$, had not been reached. The potential values, extrapolated from the anodic polarisation plots of Fig. 4 at $0.05(0.1 \mathrm{~mA})$ and $0.5 \mathrm{~mA} \mathrm{~cm}{ }^{-2}(1 \mathrm{~mA})$ current densities are approximately +0.580 and $+0.350 \mathrm{~V}$ vs. SCE, respectively when the coating thickness was $>5 \mu \mathrm{m}$.

Longer term corrosion tests over $96 \mathrm{~h}$ are presented in Fig. 5. The corrosion potentials for the 3,6 and $24 \mu \mathrm{m}$ coating thickness were higher than for the bare aluminium substrate and the $5 \mu \mathrm{m}$ coating and remained fairly constant for approximately $48 \mathrm{~h}$. After this time, the samples coated with 3 and $6 \mu \mathrm{m}$ EN developed pores resulting in a potential decreasing. The $12 \mu \mathrm{m}$ (not shown) and $24 \mu \mathrm{m}$ thickness EN nickel coatings show no evidence of corrosion over the time period considered.

\subsubsection{Linear polarisation resistance and corrosion current monitoring}

The linear polarisation measurements of the EN coated Al samples immersed in $0.85 \mathrm{~mol} \mathrm{dm}^{-3}$ (5\%) $\mathrm{NaCl}$ solution can be seen in Fig. 6 . The curve shows that the corrosion rate decreases drastically from $\approx 0.52 \mathrm{~mm} \mathrm{yr}^{-1}$ for the bare aluminium, to $\approx 0.01 \mathrm{~mm} \mathrm{yr}^{-1}$ for nickel coatings of more than $3 \mu \mathrm{m}$ thickness. The results are comparable with a Tafel analysis which showed that the corrosion rate decrease from 0.04 to $0.01 \mathrm{~mm} \mathrm{yr}^{-1}$. The slightly higher initial results are attributed to the $24 \mathrm{~h}$ stabilisation required for the 2-probe LPR method in comparison to a typical time of $15 \mathrm{~min}$ required for a Tafel analysis. The $3 \mu \mathrm{m}$ EN thickness showed an averaged penetration rate of less than $0.1 \mathrm{~mm} \mathrm{yr}^{-1}$ by both methods and the corrosion rates indicate substantial decrease in the porosity of the nickel coating. These corrosion rates compare values reported by Zeller of less than $1 \mathrm{~mm} \mathrm{yr}^{-1}$ in high phosphorus electroless nickel coatings on cold-rolled steel immersed in $0.85 \mathrm{~mol} \mathrm{dm}^{-3}(5 \%) \mathrm{NaCl}$ [38].

\subsection{Porosity measurements on electroless nickel deposits on a mild steel substrate}

\subsubsection{Tafel extrapolation (log current density vs. potential) diagrams}

Pyrene steel and electroless nickel coated pyrene steel samples were examined. The values of the corrosion current density obtained from Tafel plots were to calculate the corrosion resistance of different nickel coating thickness [39]. Some typical results are shown in Fig. 7 a) and in Table 2.

Fig. 7 a) shows that the $24 \mu \mathrm{m}$ thickness EN deposit on mild steel gave rise to cathodic Tafel slopes between -0.19 to $-0.20 \mathrm{~V}$. In comparison, pyrene steel and the other EN deposits show lower Tafel slopes of approximately 0.10 to $0.14 \mathrm{~V}$. This variation is due to the incomplete reduction of residual oxide films during cathodic polarisation. These films are not efficient cathodes as the oxide free surfaces (i.e., a lower $j_{0}$ ) and indicate that hydrogen reduction is not the only cathodic reaction; reduction of surface oxides might also occur. For thicker deposits, the value of $E_{\text {cor }}$ is just above the hydrogen evolution line $\left(\mathrm{H}^{+} / \mathrm{H}_{2}\right)$ on a $E-\mathrm{pH}$ diagram. This will result in insufficient hydrogen being generated when the electrode was polarised to approximately $0.20 \mathrm{~V}$ below the value of $E_{\mathrm{cor}}$, for the removal of the oxide film. The levels of current for hydrogen reduction at these potentials will be in the order of $0.01 \mu \mathrm{A} \mathrm{cm}^{-2}$. Table 2 shows that the value of $j_{\text {cor }}$ for mild steel was $61 \mathrm{~A} \mathrm{~cm}^{-2}$, while for a $24 \mu \mathrm{m}$ electroless nickel deposit was $7 \mathrm{~A} \mathrm{~cm}^{-2}$. Thin EN coatings tend to be porous and give intermediate values of $j_{\mathrm{cor}}$ and $E_{\mathrm{cor}}$. The corrosion resistance of these coatings depends on the exposed area of steel at the base of the pores.

Fig. 7 b) shows the effect of the EN deposition time (hence deposit thickness) on both, corrosion potential $E_{\mathrm{cor}}$, and corrosion current density $j_{\text {cor }}$. The corrosion potential changed from -0.45 to $-0.20 \mathrm{~V} v \mathrm{~s}$. SCE as the deposition time increased from 0 to $120 \mathrm{~min}$ while the corrosion current density decreased from approximately 0.30 to $0.005 \mathrm{~mA} \mathrm{~cm}^{-2}$ over the same period of time.

\subsubsection{Anodic polarisation and current vs. time transients}

4.2.2.1. $1 \mu \mathrm{m}$ electroless nickel coating. Fig. 8 a) shows the log current density $v s$. potential curve for $1 \mu \mathrm{m}$ thickness electroless nickel coating on mild steel substrate. The numbers on the Figure indicate the changes in the slope of the anodic polarisation plot and the points at which a constant electrolysis was carried out. The currents at these points were monitored vs. time and the results are plotted in Fig. 8 b), where the curves are identified with the numbers given to the points on Fig. 8 a). The electrolyte was analysed for nickel and iron content at the end of the electrolysis to determine the predominant anodic dissolution process, i.e., nickel or iron. The results are summarised in Table 3.

When the potential was fixed at $-0.17 \mathrm{~V}$, (point 1 on Fig. 8 a) the current density was $\approx 3 \mathrm{~mA} \mathrm{~cm}{ }^{-2}$ as seen on curve (1) Fig. $8 \mathrm{~b}$ ). At this potential there should be zero nickel dissolution whereas the iron substrate can be anodically dissolved through the pores of the coating. The data in Table 3 show a concentration of $16.5 \mathrm{ppm}$ iron dissolved while no nickel was detected at the end of the electrolysis. Point 2 on Fig. 8 a) corresponds to a metastable region for iron passivation. The potential at this point corresponds approximately to $+0.20 \mathrm{~V} v \mathrm{v}$. SCE and the curve (2) on Fig. $8 \mathrm{~b}$ ) shows the current $v$ s. time plot at this potential. The repeated fluctuation of the current readings over the period of the test clearly demonstrates the unstable nature of the film formed on the exposed iron surface at the base of the pores. This current is due to the anodic dissolution of iron as no nickel was detected in the electrolyte. At these potentials, the electroless nickel surface was still covered with a

Table 3

Concentration of dissolved nickel and iron at significant changes of the slope in the anodic polarisation curve (numbered 1-9 on Figs. 8, 9 and 10)

\begin{tabular}{|c|c|c|c|c|c|c|c|}
\hline \multirow[t]{3}{*}{$\begin{array}{l}\text { Deposition time (thickness of EN } \\
\text { deposit) }\end{array}$} & \multirow{3}{*}{$\begin{array}{l}\text { Position on } \\
\text { figures and } \\
\text { potential } \\
\text { (point) E } \\
\text { vs. SCE }\end{array}$} & \multicolumn{3}{|c|}{$\begin{array}{l}\text { Concentration of metal ion in } 0.125 \mathrm{~mol} \mathrm{dm}^{-3} \\
\mathrm{H}_{2} \mathrm{SO}_{4} \text { electrolyte/ppm }\end{array}$} & \multicolumn{3}{|c|}{$\begin{array}{l}\text { Measurements for the area under the current-time } \\
\text { curves }\end{array}$} \\
\hline & & \multirow{2}{*}{$\frac{\text { Calculated }}{\mathrm{Ni}}$} & \multicolumn{2}{|c|}{ Experimental } & \multirow{2}{*}{$\begin{array}{l}\text { Charge, } \\
\text { q/A s }\end{array}$} & \multirow{2}{*}{$\begin{array}{l}\text { Current density, } \\
j / \mathrm{mA} \mathrm{cm}^{-2}\end{array}$} & \multirow{2}{*}{$\begin{array}{l}\text { Stripping } \\
\text { time/min }\end{array}$} \\
\hline & & & $\mathrm{Fe}$ & $\mathrm{Ni}$ & & & \\
\hline \multirow[t]{3}{*}{$5 \min (1 \mu \mathrm{m})$ Fig. $8 a)$ and $8 b)$} & $(1)-0.17 \mathrm{~V}$ & - & 16.5 & 0.0 & 10.6 & 2.96 & - \\
\hline & $(2)+0.20 \mathrm{~V}$ & - & 44.9 & 0.0 & 24.0 & 6.60 & - \\
\hline & $(3)+0.60 \mathrm{~V}$ & 4.5 & 5.4 & 3.9 & 8.3 & 2.46 & 30 \\
\hline \multirow[t]{3}{*}{$15 \min (3 \mu \mathrm{m})$ Fig. 9a) and 9b) } & (4) $-0.17 \mathrm{~V}$ & - & 8.3 & 0.0 & 5.1 & 1.41 & - \\
\hline & $(5)+0.20 \mathrm{~V}$ & - & 8.7 & 0.0 & 5.2 & 1.46 & \\
\hline & $(6)+0.60 \mathrm{~V}$ & 9.9 & 0.5 & 9.7 & 11.6 & 3.21 & 30 \\
\hline \multirow[t]{3}{*}{$120 \min (24 \mu \mathrm{m})$ Fig. $10 a)$ and $10 \mathrm{~b})$} & (7) $0.00 \mathrm{~V}$ & - & 0.0 & 0.0 & 0.14 & 0.04 & - \\
\hline & $(8)+0.40 \mathrm{~V}$ & 5.4 & 0.0 & 4.5 & 5.3 & 1.48 & 102 \\
\hline & (9) $+0.65 \mathrm{~V}$ & 36.6 & 0.65 & 30 & 36.2 & 10.0 & 123 \\
\hline
\end{tabular}

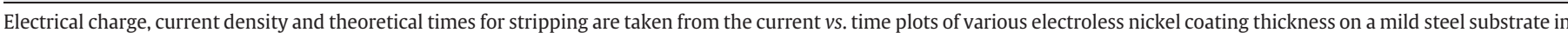
$0.1 \mathrm{~mol} \mathrm{dm}^{-3} \mathrm{H}_{2} \mathrm{SO}_{4}$ at $295 \mathrm{~K}$. 
a)

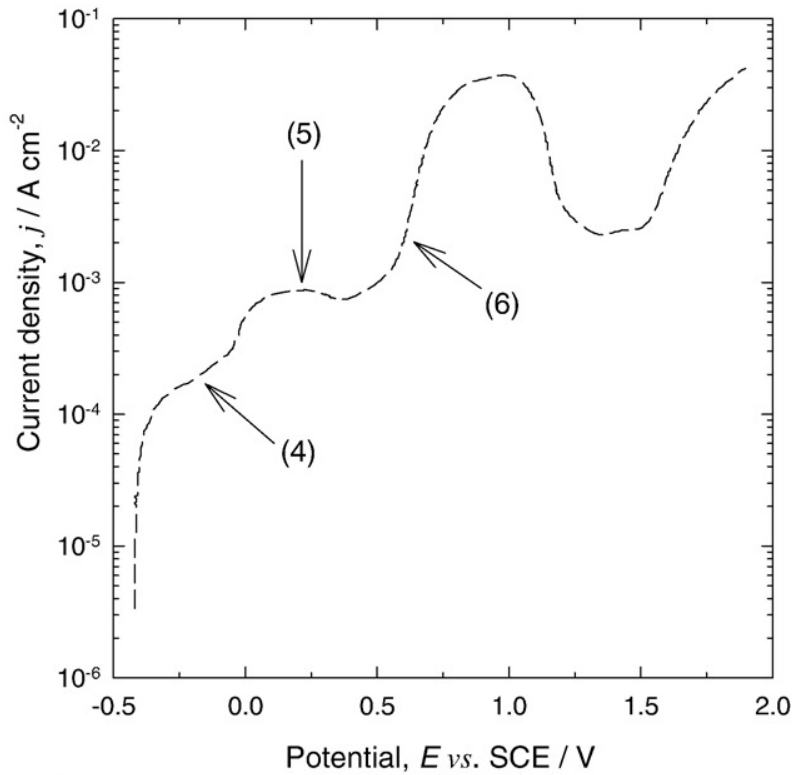

b)

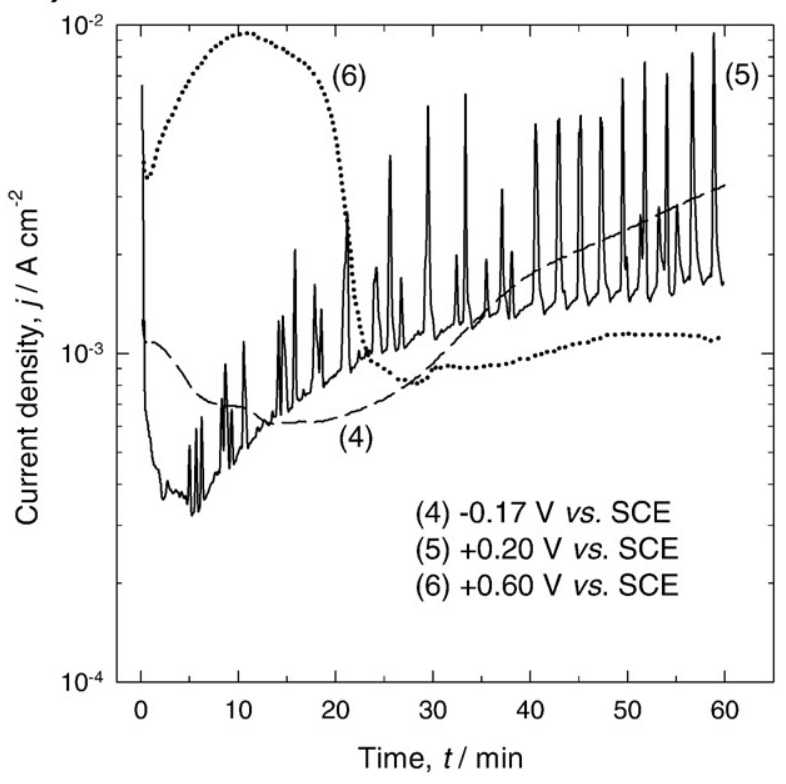

Fig. 9. a) Log current density $v s$. potential for a $3 \mu \mathrm{m}$ thickness EN coating (containing $\approx 12 \%$ wt. phosphorus) on mild steel. b) Current $v$ s. time plots at: (4) $-0.17 \mathrm{~V}$, (5) $+0.2 \mathrm{~V}$ and (6) $+0.6 \mathrm{~V} v$ v. SCE. The electrolyte $\left(0.125 \mathrm{~mol} \mathrm{dm}^{-3} \mathrm{H}_{2} \mathrm{SO}_{4}\right.$ at $\left.295 \mathrm{~K}\right)$ was analysed for $\mathrm{Ni}$ and $\mathrm{Fe}$ ions at the end of the experiment.

phosphorus type film. Table 3 shows that the iron content in the acid electrolyte was $44.9 \mathrm{ppm}$, which is appreciably higher than the concentration observed at $-0.17 \mathrm{~V}$ vs. SCE, $16.5 \mathrm{ppm}$. The current increase and decrease around the point 3 on Fig. 8 a) indicates that the protective film on the surface of the EN broke down at $\approx+0.6 \mathrm{~V} v$ s. SCE. Curve (3) in Fig. 8 b) shows the current $v$ s. time at this potential. The current increase in the region (A)-(B) of curve (3) can be due to two factors: a) breakdown of the phosphorus type film in the electroless nickel surface i.e., the current rise is the result of nickel dissolution through the phosphorus film or b) dissolution of iron at the base of the pores until the value of $i_{\text {crit }}$ has been exceeded and the iron began to passivate. Following these processes the electroless nickel deposit dissolved in the regions (B) to (C) with the current falling as the area of electroless nickel diminished.
Additional current $v s$. time transients (not shown) were recorded at points (C) and (D) on Fig. 8 b). The analysis of the electrolyte at point (C) showed no dissolved iron, which discounts the hypothesis b) above. Fluctuation of the current in the region (A) to $(\mathrm{C})$ is due solely to the dissolution of nickel from the deposit. The current density value at point (D) on Fig. 8 b) corresponds to the passivation current $i_{\text {pass }}$, for iron in the acid electrolyte at this potential. Analysis of the solution at the end of the electrolysis on point (D) indicates that $3.9 \mathrm{ppm}$ for nickel and $5.4 \mathrm{ppm}$ for iron are dissolved in the electrolyte (see Table 3). This result shows that, for a $1 \mu \mathrm{m}$ thick coating, the Ni breaks down after approximately 5 min following an applied potential of $+0.6 \mathrm{~V} v$ s. SCE. Dissolution and passivation of the iron substrate surface follow.

\section{a)}

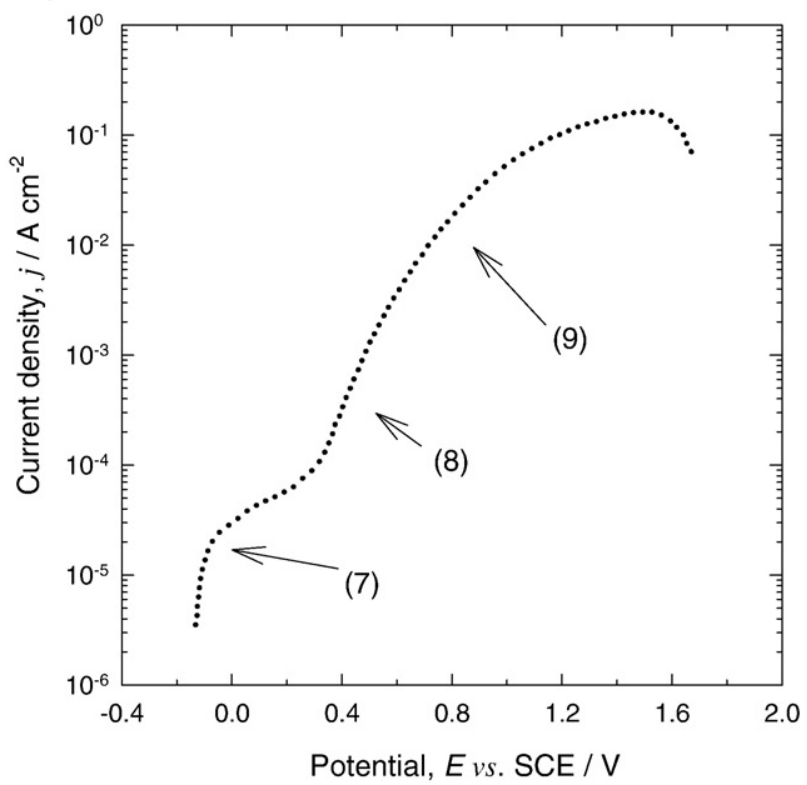

b)

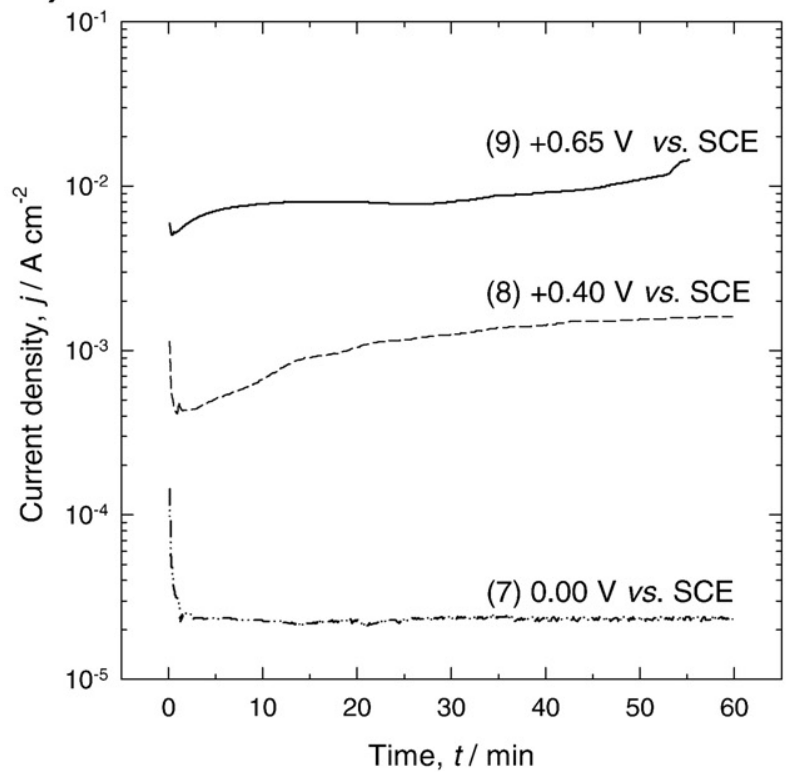

Fig. 10. a) Log current density vs. potential for a $24 \mu \mathrm{m}$ thickness EN coating containing $12 \%$ phosphorus on mild steel. b) Current $v$ s. time plots at: (7) $0 \mathrm{~V},(8)+0.4 \mathrm{~V}$ and (9) $+0.65 \mathrm{~V} v$ s. SCE. The electrolyte $\left(0.125 \mathrm{~mol} \mathrm{dm}^{-3} \mathrm{H}_{2} \mathrm{SO}_{4}\right.$ at $\left.295 \mathrm{~K}\right)$ was analysed for $\mathrm{Ni}$ and $\mathrm{Fe}$ ions at the end of the experiment. 


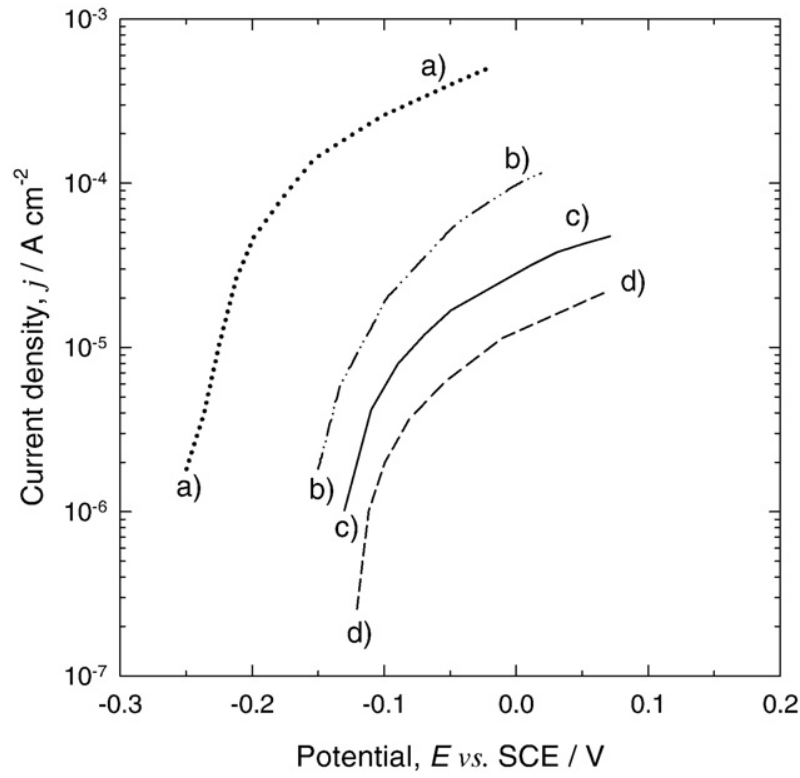

Fig. 11. Anodic polarisation curves for bare electroless copper and various submicron thick immersion gold deposits on copper-coated ABS polymer in $0.1 \mathrm{~mol} \mathrm{dm}{ }^{-3} \mathrm{NH}_{4} \mathrm{BF}_{4}$ at $295 \mathrm{~K}$. a) Bare electroless copper deposit on ABS. b) $75 \mathrm{~nm}$, c) $100 \mathrm{~nm}$ and d) $190 \mathrm{~nm}$ are the nominal thickness of Au coatings.

4.2.2.2. $3 \mu \mathrm{m}$ electroless nickel coating. A similar analysis of the $3 \mu \mathrm{m}$ thick EN deposit when the potential was held at $+0.17 \mathrm{~V} v$ s. SCE (point 4 on Fig. 9 a) shows that the corrosion current and the iron content of the electrolyte at the end of the electrolysis were $1.41 \mathrm{~mA} \mathrm{~cm}^{-2}$ and 8.3 ppm, respectively (curve (4) on Fig. 9 b). These values are lower than those found for the $1 \mu \mathrm{m}$ nickel deposit at the same potential (see Table 3). When the potential was held at $+0.2 \mathrm{~V}$ vs. SCE (point 5 on Fig. 9 a) similar current $v s$. time transient with rapid fluctuations of current (similar to the case of the $1 \mu \mathrm{m}$ thick deposit) were observed (curve (5) on Fig. 9 b)). The concentration of dissolved iron was $8.7 \mathrm{ppm}$, which was significantly lower than for the $1 \mathrm{~m}$ deposit, $44.9 \mathrm{ppm}$ (see Table 3). This may be due to the tendency of the iron surface to be covered with a passive film at longer periods of time, which is reflected in the low values of current at both -0.17 and $+0.20 \mathrm{~V}$ $v s$. SCE (Table 3). The concentration of dissolved iron at these potential was $8.3 \mathrm{ppm}$ and $8.7 \mathrm{ppm}$ respectively, reinforcing the suggestion of a passive film. When the potential was set at $+0.60 \mathrm{~V} v$ s. SCE (point 6 on Fig. 9 a) the $3 \mu \mathrm{m}$ thick nickel coating showed a fluctuation of the current, indicating breakdown of the coating (curve (6) in Fig. 9 b). The concentration of $\mathrm{Ni}$ in the electrolyte at the end of the electrolysis was $9.7 \mathrm{ppm}$ in comparison to the value of $3.9 \mathrm{ppm}$ found for the $1 \mu \mathrm{m}$ thick deposit with only $0.5 \mathrm{ppm}$ of $\mathrm{Fe}^{2+}$ at the same potential. These results show that the $3 \mu \mathrm{m}$ thick nickel coating protected the iron substrate more effectively than the $1 \mu \mathrm{m}$ one.

Table 4

Corrosion potential, $E_{\text {cor }}$ and integrated area values determined from anodic polarisation curves for bare electroless copper and various immersion gold deposit thicknesses on electroless copper in $0.1 \mathrm{~mol} \mathrm{dm}^{-3} \mathrm{NH}_{4} \mathrm{BF}_{4}$ at $295 \mathrm{~K}$

\begin{tabular}{|c|c|c|c|}
\hline Material & $\begin{array}{l}\text { Open-circuit } \\
\text { potential, } E_{\mathrm{MP}} \text { or } \\
\text { corrosion } \\
\text { potential, } E_{\text {cor }} v s \text {. } \\
\text { SCE/V }\end{array}$ & 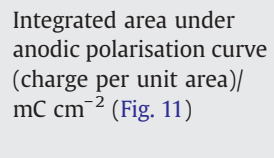 & $\begin{array}{l}\text { Integrated area } \\
\text { of } j \text { vs. } t \\
\text { transients/mC } \\
\mathrm{cm}^{-2} \text { (Fig. 12) }\end{array}$ \\
\hline Gold foil & -0.120 & - & - \\
\hline $190 \mathrm{~nm} \mathrm{Au} \mathrm{deposit}$ & -0.120 & 4.0 & 0.22 \\
\hline $100 \mathrm{~nm}$ Au deposit & -0.128 & 6.9 & 0.51 \\
\hline $75 \mathrm{~nm}$ Au deposit & -0.148 & 10.1 & 0.93 \\
\hline $\begin{array}{l}30 \mu \mathrm{m} \text { electroless } \\
\text { copper deposit }\end{array}$ & -0.250 & 52.2 & 1.20 \\
\hline
\end{tabular}

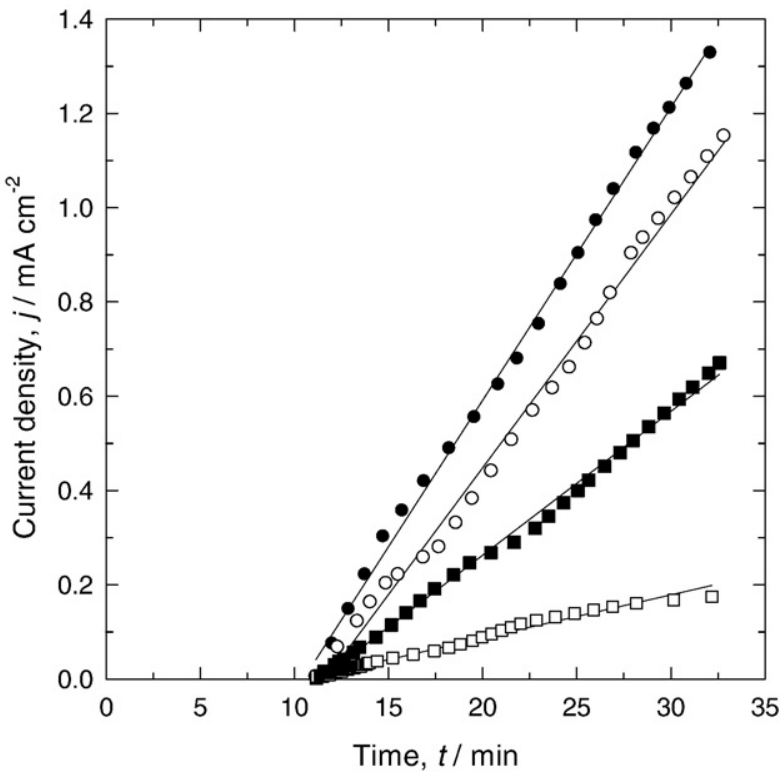

Fig. 12. Current density $v s$. time curves for an electroless copper-covered ABS substrate and various immersion gold deposits on the copper in $0.1 \mathrm{~mol} \mathrm{dm}^{-3} \mathrm{NH}_{4} \mathrm{BF}_{4}$ electrolyte, at $295 \mathrm{~K} . \bullet$ ) Bare electroless Cu on ABS of $30 \mu \mathrm{m}$ thickness. Thickness of Au coatings: O) $75 \mathrm{~nm}, \mathbf{\square}) 100 \mathrm{~nm}$, and $\square) 190 \mathrm{~nm}$.

4.2.2.3. $24 \mu \mathrm{m}$ electroless nickel coating on mild steel. For a $24 \mu \mathrm{m}$ thick EN deposit, the potential was held at $0 \mathrm{~V} v \mathrm{~s}$. SCE, corresponding to point 7 in Fig. 10 a). At this potential the phosphorus type film suppresses nickel dissolution and no nickel ions were detected in the electrolyte as it is shown in Table 3. As expected, the current density at this potential is very low; $<0.04 \mathrm{~mA} \mathrm{~cm}^{-2}$ (curve (7) Fig. $10 \mathrm{~b}$ ). Further increase in the potential to $+0.4 \mathrm{~V} v$ s. SCE (point 8 Fig. 10 a) showed no $\mathrm{Fe}^{+2}$ ions at the end of the electrolysis and $4.5 \mathrm{ppm}$ of $\mathrm{Ni}$ ions in the electrolyte (curve (8) Fig. $10 \mathrm{~b}$ ). At this potential, the phosphorus film covering the surface of the $24 \mathrm{~m}$ deposit begins to break down. The coating is expected to be essentially pore-free and this is reflected in the results of the current $v s$. time plots at the potentials indicated as points 7 and 8 in Fig. 10 a). At these potentials the concentration of iron was below the detection limit of the analytical method ( 0.005 to $0.01 \mathrm{ppm}$ ). Increasing the potential to

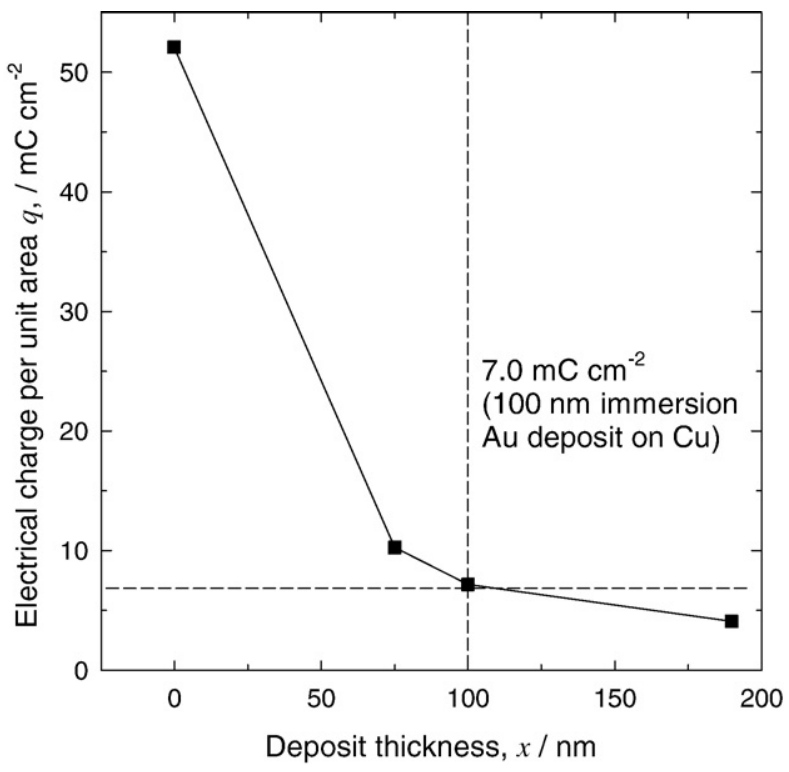

Fig. 13. Immersion gold deposits on an electroless copper of $30 \mu \mathrm{m}$ thickness deposited on an ABS plastic substrate. Assessment of the extent of deposit porosity at $295 \mathrm{~K}$. 
$+0.65 \mathrm{~V} v$ s. SCE causes a dramatic increase in current density to $10 \mathrm{~mA}$ $\mathrm{cm}^{-2}$ (curve (9) Fig. $10 \mathrm{~b}$ ) which indicates a rapid dissolution of the deposit. Point 9 on Fig. 10 a confirms that the dissolution of the coating is rapid at this potential as the $i_{\text {crit }}$ value for EN dissolution is approached. This is reflected in the high concentration of nickel ions in the electrolyte, $30 \mathrm{ppm}$ (see Table 3). The substrate at this potential is still protected by the Ni coating as is reflected by the low concentration of $\mathrm{Fe}^{+2}$ ions.

4.2.2.4. Predicted and experimental concentrations of $\mathrm{Ni}^{2+}$ in the electrolyte. To verify that the high currents observed at $+0.6 \mathrm{~V}$ and $+0.65 \mathrm{~V} v$ vs. SCE are due to dissolution of the electroless nickel coating, the predicted amount of nickel for each deposit thickness that would dissolve into the electrolyte as $\mathrm{Ni}^{2+}$ was calculated from Faraday's law (assuming $100 \%$ efficiency). It was also possible to determine the time taken to completely dissolve the deposit for the current values measured (see Table 3). The area under the current vs. time curve is equivalent to the electrical charge passed per mole, i.e., A s mol${ }^{-1}$. For example, a $1 \mu \mathrm{m}$ deposit at a fixed potential of $+0.6 \mathrm{~V}$, gave a value of 8.3 coulombs. This is equivalent to a current density of $2.5 \mathrm{~mA} \mathrm{~cm}{ }^{-2}$ (Table 3), which would result in the complete dissolution of the deposit from a $1 \mathrm{~cm}^{2}$ area in $30.3 \mathrm{~min}$. This should have resulted in a predicted concentration of $4.5 \mathrm{ppm}$ of nickel in the $300 \mathrm{~cm}^{3}$ electrolyte (Table 3). Experimentally, a value of $3.9 \mathrm{ppm}$ was observed, which is in reasonable agreement with the predicted value and supports the argument that EN deposit corrodes at this potential. The discrepancy between the two values is partly due to the neglect of the inclusion of $12 \%$ of phosphorus in the deposit. A similar argument can be used to explain the differences between theoretical and experimental results for the 3 and $24 \mu \mathrm{m}$ electroless nickel deposits.

\subsection{Porosity measurements for immersion gold/electroless deposits on copper-coated ABS plastic [23,40,41]}

\subsubsection{Anodic polarisation and current-time transients}

Fig. 11 shows the logarithm of the current density vs. potential plots for the copper coated ABS samples with a gold layer of different thicknesses immersed in $0.1 \mathrm{~mol} \mathrm{dm}{ }^{-3} \mathrm{NH}_{4} \mathrm{BF}_{4}$. The open-circuit potential of each sample increases with the thickness of the gold coating and the thicker coating of $190 \mathrm{~nm}$ (curve d) has an opencircuit potential value similar to the gold foil electrode. The plots on the Figure also show that at the same potential the thicker coatings present lower current density. The integration of the polarization curves shows larger electrical charges for thinner gold deposits which might indicate large number pores on thinner coatings (Table 4 column 3). Fig. 12 shows the anodic current density vs. time measured at the open-circuit potential for each gold coating thickness. The plots show that after approximately $10 \mathrm{~min}$, the current increases linearly with time, with higher gradients observed for thin electroless gold coatings and for the bare copper coated ABS polymer. These currents are due to the gradual opening of the pores in the gold coating with time. It was assumed that most of this current is due to the oxidation of the copper substrate since the corrosion of gold in the ammonium tetrafluoroborate solution occurs at very lower rate. Thinner deposits lead to more rapid oxidation of the substrate through the gold coating pores. The integration of the current density $v s$. time plots shows that the charge passed at the open-circuit potential for a copper substrate $\left(1.20 \mathrm{mC} \mathrm{cm}^{-2}\right)$ was over 5 times larger than that for the $190 \mathrm{~nm}$ gold coated sample $\left(0.22 \mathrm{mC} \mathrm{cm}^{-2}\right)$. Intermediate gold thickness deposits exhibited charge densities between these two values, as shown in column 4 of Table 4.

From these data, the relationship between thickness and porosity in Eq. (1), together with the relationship between the degree of porosity and the magnitude of the current flowing through the coated sample, can be established. The $190 \mathrm{~nm}$ thick gold deposit showed the lowest oxidation profile and was assumed to be essentially pore-free, while the electroless copper sample was $100 \%$ porous. By plotting the electrical charge from

the polarization curves (column 3 Table 4) vs. the nominal thickness of the gold electroless coating, (column 1 Table 4) Fig. 13) shows that an estimation of deposit porosity can be made. An acceptable limit of the thickness of the deposit could be considered, for example, if a deposit produced a charge density of less than $7.0 \mathrm{mC} \mathrm{cm}^{-2}$, the deposit porosity can be considered to be low and the coating is expected to provide an effective barrier to corrosion. The trends shown by the anodic polarisation diagrams were similar to those shown by the current $v$ s. time plots.

A galvanic couple can be formed between the exposed electroless copper at the base of the pores, and the immersion gold deposit. The potential of this couple, the mixed potential, $E_{M P}$, will lie between the potential of the substrate and a pore free coating. As the amount of porosity decreases, i.e., with increased deposit thickness, the $E_{M P}$ will become more noble due to pore reduction. Similarly, there must be a reduction in the corrosion current and the charge density.

\section{Summary}

Conventional porosity tests, such as salt spray or electrographic methods, are time consuming and the results can be ambiguous and qualitative. There is a clear need for non-ambiguous quantitative methods that can provide rapid, accurate and reliable approach to asses the porosity of a deposit. Electrochemical techniques can prove beneficial in alleviating some of the drawbacks observed in conventional porosity tests. Electrochemical impedance spectroscopy (EIS) is a reliable and robust technique to determine the porosity of electrochemical coatings but expensive equipment is required. In addition, experience and skills are required for the correct interpretation of the electrical circuits and their comparison with the physical experimental parameters.

The electrochemical porosity tests highlighted in this paper included d.c. techniques which are easier to interpret and provide similar results as the EIS technique without the complications. Such techniques included: linear polarisation resistance, Tafel extrapolation, anodic polarization and current $v s$. time transients. The test were carried out in specifically chosen electrolytes, as this choice is critical for porosity determination, i.e., the electrolyte must maximise the corrosion of the substrate with minimal destruction of the coating material.

The determination of porosity by electrochemical techniques can be an effective alternative to more conventional chemical tests. d.c. tests identified the presence of pores on the coatings of aluminium, mild steel and Cu-plated ABS polymer substrates, illustrating that these electrochemical techniques have a wide variety of applications, which are not specific to one coating/substrate combination.

$\begin{array}{lll}\text { List of symbols } & \\ \text { Symbol } & \text { Meaning } & \text { Units } \\ A & \text { Constant in Eq. (2) } & \text { Dimensionless } \\ K & \text { Constant in Eq. (8) } & \mathrm{V} \\ E^{0} & \text { Standard potential } & \mathrm{V} \\ E & \text { Electrode potential } & \mathrm{V} \\ E_{c} & \text { Cathode potential } & \mathrm{V} \\ E_{\text {cor }} & \text { Corrosion potential } & \mathrm{V} \\ E_{\text {meas }} & \text { Measured potential } & \mathrm{V} \\ E_{\mathrm{MP}} & \text { Mixed potential } & \mathrm{V} \\ j & \text { Current density } & \mathrm{A} \mathrm{cm}{ }^{-2} \\ j_{\text {cor }} & \text { Corrosion current density } & \mathrm{A} \mathrm{cm} \\ j_{\text {crit }} & \text { Critical current density } & \mathrm{A} \mathrm{cm}^{-2} \\ j_{\text {pass }} & \text { Passivation current density } & \mathrm{A} \mathrm{cm}{ }^{-2} \\ j_{0} & \text { Exchange current density } & \mathrm{A} \mathrm{cm}^{-2} \\ N & \text { Constant in Eq. (1) and (2) } & \text { Dimensionless } \\ P & \text { Porosity of the coating } & \text { Dimensionless } \\ q & \text { Electrical charge } & \mathrm{C} \\ \chi & \text { Deposit thickness } & \mathrm{nm} \mathrm{and} \mu \mathrm{m}^{-1} \\ \beta_{a} & \text { Anodic Tafel slope } & \mathrm{V} \mathrm{decade}^{-1} \\ \beta_{c} & \text { Cathodic Tafel slope } & \mathrm{V} \mathrm{decade}^{-1}\end{array}$

List of symbols

Symbol Meaning

$E_{\text {cor }} \quad$ Corrosion potentia

$E_{\text {meas }} \quad$ Measured potentia

$E_{\mathrm{MP}} \quad$ Mixed potential

$j \quad$ Current density

$j_{\text {cor }} \quad$ Corrosion current density

$j_{\text {crit }} \quad$ Critical current density

$j_{\text {pass }}$

$P$

$x$

$\beta_{a}$ Cathodic Tafel slope
V

V

V

$\mathrm{A} \mathrm{cm}^{-2}$

$\mathrm{A} \mathrm{cm}^{-2}$

$\mathrm{A} \mathrm{cm} \mathrm{cm}^{-2}$

$\mathrm{A} \mathrm{cm}^{-2}$

$\mathrm{A} \mathrm{cm}^{-2}$

Dimensionless

C

$V$ decade $^{-1}$

$\mathrm{V}$ decade $^{-1}$ 
$\eta_{c}$

Cathodic polarization

$\mathrm{V}$

Anodic polarization

\section{References}

[1] W. Riedel, "Electroless Nickel Plating”, Finishing Publications Ltd, Stevenage, England, 1991.

[2] Y.Z. Zhang, M. Yao, Trans. Inst. Met. Finish 77 (1999) 78.

[3] R.L. Zeller, L. Salvatii, Corr. Sci. 50 (1994) 457.

[4] R. Parkinson, "Properties and Applications of Electroless Nickel Deposits", Nickel Development Institute, Technical Series No. 10081, 1997.

[5] J.P. Celis, J.R. Roos, C. Fan, Trans. Inst. Met. Finish 69 (1991) 15.

[6] R.N. Duncan, Plating. Surf. Finish 83 (1996) 64.

[7] C. Kerr, B.D. Barker, F.C. Walsh, Trans. Inst. Met. Finish 74 (1996) 214.

[8] R.A. Jeanmenne, Plating Surf. Finish.81 (1994) 39.

[9] G.W. Reade, C. Kerr, B.D. Barker, F.C. Walsh, Trans. Inst. Met. Finish 76 (1998) 149

[10] P. Ernst, I.P. Wadsworth, G.W. Marshall, Trans. Inst. Met. Finish 75 (1997) 194

[11] L. Das, D.T. Chin, G.L. Evarts, R.L. Zeller, Plating Surf. Finish. 84 (1997) 66.

[12] H. Deng, M. Molller, Plating Surf. Finish. 81 (1994) 73.

[13] K. Parker, Plating Surf. Finish. 79 (1992) 29.

[14] P. Leisner, M.E. Benzon, Trans. Inst. Met. Finish 75 (1997) 88

[15] C. Kerr, B.D. Barker, F.C. Walsh. "Electrochemical techniques for the evaluation of porosity and corrosion rate for electroless nickel deposits on steel". Proc., Corrosion 1997, paper 269. March 9-14, New Orleans, Louisiana, USA.

[16] J. Creus, H. Mazille, H. Idrissi, Surf. Coat. Tech. 130 (2000) 224.

[17] P. Pawar, A.B. Gaikwad, P.P. Patil, Electrochim. Acta 52 (2007) 5958.

[18] F. Sittner, W. Ensinger, Thin Solid Films, 518 (2007) 4559.

[19] C. Kerr, B.D. Barker, F.C. Walsh, Trans. Inst. Met. Finish 74 (1996) 214
[20] C. Kerr. 'Porosity of Electroless Nickel Coatings on Mild Steel Substrates' PhD thesis, University of Portsmouth UK (1997).

21] G.W. Reade, C. Kerr, D.B. Barker, F.C. Walsh, Trans. Inst. Met. Finish 76 (1998) 149

[22] A.H. Nahlé, C. Kerr, B.D. Barker, F.C. Walsh, Trans. Inst. Met. Finish 76 (1998) 29.

[23] I.M. Notter, D.R. Gabe, Corr. Rev. 10 (1992) 217.

[24] J. Zhang, V. Desai, Surf. Coat. Technol. 190 (2005) 98

[25] S.H. Ahn, J.H. Lee, H.G. Kim, J.G. Kim, Appl. Surf. Sci. 233 (2004) 105

[26] J. Creus, H. Mazille, H. Idrissi, Surf. Coat. Technol. 130 (2000) 224-232.

[27] M.G. Fontana, “Corrosion Engineering”, 3rd edn, McGraw-Hill, New York, 1997, pp. 50-55.

28] L.M. Callow, J.A. Richardson, J.L. Dawson, Br. Corros. J. 11 (1976) 123.

[29] M. Stern, Proc. ASTM 59 (1959) 1280.

[30] K.R. Trethewey, J. Chamberlain, “Corrosion: for Science and Engineering”, 2nd edn, Longman, (UK), 1995.

[31] M.L. Rothstein, Plating Surf. Finish 73 (1986) 44.

[32] E.M. Pater, S. Bruckenstein, Electrochem. Comm. 5 (2003) 958

[33] P.E. Morris, R.C. Scarberry, Corrosion 26 (1970) 169

[34] T. Våland, G. Nilsson, Corrosion Sci., 16 (1976) 591.

[35] D. Crotty, B. Clark, J. Greene, B. Durkin, Plating Surf. Finish. 79 (1992) 42.

[36] M. Zitco, P. Vignati, Advances in electroless nickel and post treatment for enhanced corrosion protection of aluminium connectors, Proc 80th AESF Annual Technical Conference (1993) 1001.

[37] S. Court. "Characterization of Electroless Nickel Coatings on Aluminium and Steel Substrates". PhD Thesis, University of Portsmouth, 2002.

[38] R.L. Zeller, Corrosion Sci. 47 (1991) 692.

[39] C. Kerr, B.D. Barker, F.C. Walsh, Trans. Inst. Met. Finish 75 (1997) 81.

[40] F. Mansfeld, Corrosion 27 (1971) 436.

[41] R.J. Morrissey, J. Electrochem Soc. 117 (1970) 742. 